УАK $1: 316$

ББК 60.027

DOI 10.22394/1682-2358-2018-4-72-77

S.O. Goroshchuk, postgraduate student of the Theory of Law Department, Povolzhsky Institute of Management named after P.A. Stolypin, Branch of the Russian Presidential Academy of National Economy and Public Administration

P.A. Zelensky, Candidate of Sciences (Law), Docent of the Theory of Law Department, Povolzhsky Institute of Management named after P.A. Stolypin, Branch of the Russian Presidential Academy of National Economy and Public Administration

\section{CIVIL SOCIETY \\ AND THE STATE: \\ MODERN ISSUES \\ OF INTERACTION}

The article deals with the development of scientific ideas about civil society, its structure, features and problems of correlation with the state. The features of the formation of civil society in the modern period of historical development are analyzed. The conditions and prospects of further development of civil society in Russia are substantiated.

Key words and word-combinations: the state, civil society, forms of interaction, public associations.
С.О. Гороиукк, аспирант кафедри теории права Поволжского института управления имени П.А. Стольпина - филиала Российской академии народного хозяйства и государственной службо при Президенте РФ (email: kail1992@mail.ru)

П.А. Зеленский, кандидат юридических наук, дочент кафедри теории права Поволжского института управления имени П.А. Стольппина филиала Российской академии народного хозяйства и государственной службь при Президенте РФ (email: selenskii_pave@mail.ru)

\section{ГРАЖААНСКОЕ ОБЩЕСТВО И ГОСУААРСТВО: СОВРЕМЕННЫЕ ПРОБАЕМЫ ВЗАИМОАЕЙСТВИЯ}

Аннотация. Рассматриваются вопросы развития научных представлений о гражданском обществе, его структуре, признаках, проблемах соотношения с государством. Анализируются особенности формирования современного гражданского общества. Обосновываются условия и перспективы дальнейшего развития гражданского общества в России.

Ключевые слова и словосочетания: государство, гражданское общество, формы взаимодействия, общественные объединения.

$\Gamma$ роблемы соотношения и взаимоАействия государства и гражАанского общества всегда были и остаются одними из наиболее актуальных в государственно-правовой науке. От вариантов их разрешения во многом зависит качественный уровень жизни и УАовметворение потребностей,

72 Bulletin of the Volga Region Institute of Administration • 2018. Vol. 18. № 4 
обеспечение прав и законных интересов мюдей, развитие общества в целом. КАючевую роль в этом проџессе приобретают методы управленческого возАействия государства на общественные отношения, с оАной стороны, и возможность общества влиять на юридическое содержание принимаемых властью государственных решений, составцяющих смысл политического участия в государственном управлении. Актуальны эти вопросы и для России.

Происхождение термина «гражданское общество» тесно связано с особенностями его практического применения. Аанное понятие зародияось в европейском обществе еше в период Античности. Словосочетание «Civil Society», используемое в Европе, восходит к матинскому термину «Societas civilis». В греческом полисе частная собственность не была неприкосновенна, так как в нем социальное сообщество граждан соединямось с государством. По мнению Аристотеля, всегда и во всем предпочтение следовало отдавать общему интересу. Античный полис явцялся основополагающим началом, которому помитически и экономически принадмежкам каждый индивид. Вне зависимости от своего положения он полностью зависел от полиса, поскольку частное и общественное отождествмялось [1, с. 260] .

Теоретическая конџепџия гражданского общества сформировалась только в Новое время и была взаимосвязана с теорией обшественного договора. $\mathrm{O}_{\mathrm{A}^{-}}$ ним из ее основатемей явмяется Т. Гоббс. По его мнению, государство явмяется субъектом, способным обуздать Аюдей, а общество само по себе подвержено опасности самоуничтожения. Политические отношения преАставмяли собой проблему общественного развития, управцяемого государством, которое устанавливает основы гражданского общества и регулирует порядок в нем. Английский философ Аж. Аокк, напротив, отдает предпочтение обшеству, а не государству.

По мнению американского просветителя Т. Пейна, автора трактата «ЗАравый смысм», государство преАставляет собой необходимое змо, и его вмасть необходимо ограничивать в пользу гражданского общества, которое строится на принципе самоуправления. Аля его эффективного функционирования необходимы мишь минимальные политические механизмы. Аанный подход стал основой известного тезиса «государство - ночной сторож».

Согласно конџепции французского социолога А. де Токвимя, гражданское общество представляет собой отличную от государства сферу, свободную от его влияния. В труде «О демократии в Америке» он подчеркивал, что основную ячейку гражданского общества составмяет община. Ее развитие означает развитие гражданского общества, а поскольку ее образование преАшествует государствообразованию, гражданское общество не зависит от него [1, с. 261] . Общины позволяют государству вмешиваться в свою деятельность, только когАа это затрагивает всеобщий (соџиальный) интерес. Община в Аанном случае составляет дополнительный гарант гражАанской этической равноценности граждан, осуществляя их нравственное воспитание.

По мнению американского ученого О. Энкарнасьона, все организации, образованные частными гражданами, защищающие их интересы и ценности, входят в гражданское общество. Опираясь на данную конџепџию, гражданское обще- 
ство можно разделить на два уровня: нижний, включающий в себя все организации, созданные гражданами например, товарищество собственников жилья и верхний, охватывающий иерархически организованные группы, важнейшими из которых явцяются общенациональные союзы и этнические организации [2] .

Г.В.Ф. Гегель считац, что гражАанское общество - это особая стадия Авижения от семьи к государству и составцяет комплекс субъектов гражАанского

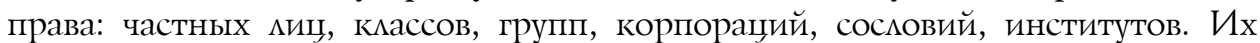
взаимодействие регулируется частным правом, и они напрямую не зависят от государства [3, с. 225].

В XVIII в. в странах Западной Европы сформировались основные ценности и элементы гражданского общества, Аействующие и в настоящее время: мичная безопасность; принцип правового равенства; право на частную собственность; право на частную жкизнь; признание естественности индивидуальных размичий, способствующих формированию уважения к Аругому человеку.

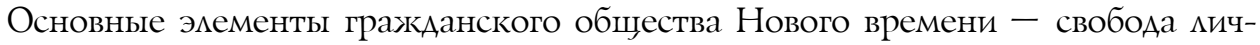
ности и право частной собственности. По мнению Б.Н. Чичерина, гражАанское общество формируется всеми частными отношениями, регулируемыми нормами права [4, с. 674].

На протяжении веков менялись научные представления о гражданском обществе, его структуре и содержкании. Развивалась и практика реализаџии идей гражжанского общества. РазАичные государства в те или иные исторические периоды приближались к их практическому воплощению мибо, наоборот, отдалялись от них. Существует мнение, что настоящее, истинное гражданское общество - это нереализуемая на практике конструкция, идеал, к которому

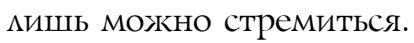

В соответствии с Конституџией страны Россия есть демократическое федеративное правовое государство с респубциканской формой государственного правления, важнейшим признаком которого явцяется нацичие гражданского общества. Развитие гражданского общества в Российской Федераџии кардинальным образом отличается от уже существующих в Аругих государствах. Его Аолгое формирование связано прежде всего с историей и менталитетом российских гражкаан.

Необходимость развития гражданского общества, заинтересованность государства в его укреплении подтверждают слова В.В. Путина: «Все больше ююдей стремится участвовать в жкизни своей страны, браться за соџиально значимые проекты, приносить реальную пользу. Аобровольчество и меценатство имеют в России глубокие корни, а чувство гражАанского Аолга, патриотизм, доброта, милосердие всегда явцяиись нашими базовыми ценностями. В этом мощнейший ресурс развития России» [5]. В известном смысле гражданское общество - это социальная сфера государства, в которой граждане имеют возможность соблюдать и исполнять имеющиеся у них субъективные права и обязанности, проявцять правовую и политическую активность. Следовательно, возникновение гражданского общества тесно связано с появлением правового государства. При этом гражданское общество не только развивается совместно с государством, но и вцияет на его развитие.

74 Bulletin of the Volga Region Institute of Administration • 2018. Vol. 18. № 4 
У российских ученых-правоведов, исследующих проблемы гражданского общества, не сложилось единого опредемения понятия, представлений о структуре гражданского обшества и системе признаков, характеризующих данный феномен. Тем не менее большинство ученых сходятся во мнении, что гражданскому обществу свойственны следующие признаки: экономическая свобода, разделение властей, плюрализм в политической и идеологической сферах, взаимная ответственность государства и граждан [6] .

Во второй половине 1980-х - начале 1990-х годов одну из главных задач, стоявших перед Российским государством, составляла необходимость раздемения функций государства и общества. В известной мере она существует и сегодня. Это означает четкое определение круга общественных отношений, не подпадающих под прямой государственный контроль. Существующее многообразие форм правовой и политической организации гражАан - это огромный общенациональный ресурс, использование которого необходимо дмя развития страны. Исторический опыт свидетельствует, что формирование гражданского обшества невозможно, если у граждан не развито чувство ответственности в отношении проблем, затрагивающих государственные и общественные интересы. Очевидна и обязанность государства оказывать общественным объединениям всестороннюю подАержку и позволять им самостоятельно решать важные вопросы, влияющие на государство.

На развитие российского гражданского общества огромное воздействие оказали реформы, проводившиеся в последнее десятилетие XX столетия. Слом Аействовавшей тоталитарной коммунистической системы осуществлялся поА цозунгом строительства правового государства с рыночной экономикой и гражданским обществом. ОАнако на деме государство отказалось от принщипа социальной справедливости, результатом чего стало падение жизненного уровня граждан. Государство фактически отказалось от выполнения своего долга перед населением, поэтому радикальным образом возросла криминализаџия общества.

В выступлении 2004 г. Президент РФ В.В. Путин обращал внимание на ошибки, совершенные в периоА становления новой российской государственности: «Аеструктивные процессы развала государства при распаде СССР перешли на нашу страну. Стремление мюдей к демократическому государству привело к возникновению политических спекулящий вместе с огромными просчетами при осуществлении экономических и соџиальных преобразований. Все это привело на тот момент к очень тяжелым последствиям. Треть населения оказалась за чертой бедности. Обычным делом стали постоянные задержки по выплате пенсий и заработной платы. Аефолт и потеря всех своих накоплений привеки к тому, что граждане перестали верить в способность государства дать даже минимальные социальные гарантии» [7] .

Сегодня уровень развития гражданского общества в России позволяет гражАанам с помощью социальных сообществ решать возникающие проблемы, а государству, в свою очередь, ослабить контроль наА деятельностью общественных объединений, что приводит к возрастанию их активности и иниџиативности. В стране широкое развитие получимо гражданское Авижение, растет 
число культурных, экономических и гражданских объединений. Вместе с тем большинство из них не отличаются профессионализмом, отстаивают интересы конкретных узких групп мюдей, а не всех граждан.

Отдельные структуры гражданского общества выходят из граниџ неполитичности, в результате чего возникает вопрос о причастности этих объединений к гражданскому обществу. В отдаленной перспективе гражданское общество можкно рассматривать как государство в государстве.

Усложнение структуры гражданского общества и рост самостоятельности его элементов приводит, по мнению А. Хлопина, к тому, что каждый из них приобретает Аолю своей самодостаточности, а это не позволяет в полной мере отражать общественные интересы и препятствует соџиальному взаимоАействию межАу Аействующими Аобровольными объеАинениями в российском третьем секторе [8, с. 137]. Существующие объединения, во-первых, не обладают полной информацией о действующих родственных организациях; во-вторых, они не стремятся объединиться с ними, так как не осознают намичия общих интересов. Именно это составцяет проблему их качественного развития.

Отметим, что взаимодействие гражданского общества с органами государственной власти и органами местного самоуправцения может носить скрытый и негативный характер и осуществцяться с помощью незаконных способов. Идеальное гражАанское общество Аолжно предоставлять всем равные возможности на основе принципа соџиальной справедцивости и соџиальной солидарности [9], поэтому в обязанности государства входит не только повышение инициативности населения, но и улучшение экономической составцяющей, то есть системы соџиальной подАержки. Экономическая и политическая стабицьность составцяет основу существования гражданского общества, поэтому соџиальное государство обязано удецять самое пристальное внимание установцению экономического порядка.

Во взаимодействии государства и общества в России наблюдается серьезное противоречие, присутствующее в законотворческом менталитете. Аостаточно часто принимаются расплывчатые, двусмысленные и неопределенные законоАательные нормы, результатом чего становится возникновение юридических комлизий и сложных ситуащий в регулировании общественных отношений. Принятие таких актов можно объяснить простым методом их реализации, и они не оказывают существенного вцияния на деятельность органов государственной вмасти. Прерогатива официального толкования таких правовых норм принадлежит государству.

ГражАанское общество и государство взаимосвязаны Аруг с Аругом, гарантии государства в общественной жизни даются совместно с гражданским обществом. Становление правового государства влечет за собой развитие и гражданского общества, так как происходит увеличение его возможностей. ОАнако этот процесс требует соблюдения следующих условий: всеобщего равенства переА законом; качественного развития общественных объединений; отсутствия у граждан корыстных побуждений при участии в общественной деятельности; повышения степени взаимодействия межАу родственными ор-

76 Bulletin of the Volga Region Institute of Administration • 2018. Vol. 18. № 4 
ганизациями и улучшения результатов их деятельности; искмючения коррупционной составцяющей во взаимоотношениях гражданского общества с органами государственной власти; экономической основы [10, с. 3-4] .

По нашему мнению, гражданское общество в России находится в стаАии активного формирования. Аля ускорения его становмения и развития необходимо, во-первых, обеспечить возможность наиболее полной реализации гражданских, политических и социальных прав граждан. Во-вторых, следует развивать механизмы «обратной связи» межАу обществом и государством, формы общественного контромя, направленные на повышение качественного уровня работы общественных объединений Аля максимацьного удовлетворения законных интересов граждан. В-третьих, целесообразно усилить контроль над правомерностью Аеятельности общественных объединений, минимизировать использование общественных структур дия «прикрытия» противоправных действий (мошенничества, коррупционных схем и др.).

Гражаанское общество в России на современном этапе динамично развивается, усложняется, с каждым годом все активнее участвуя в политической жизни. ОАнако все еще остаются проблемы, не позволяющие утверждать, что гражданское общество окончательно сформировано и эффективно функционирует. Решение актуальных социальных, экономических, политических и иных проблем требует развития механизмов взаимодействия кичности, общества и государства, каналов «обратной связи» между Аанными субъектами. Аля достижения этих важнейших целей необходимо пройти еще Аостаточно большой путь развития, прикладывать взаимные усилия как со стороны общества, так и со стороны государства.

\section{Библиографический список}

1. Ланщов С.А. Политология: учебник. СПб., 2011.

2. Энкарнасьон О.Г. Миссионеры Токвиля. Пропаганда гражданского общества и поддержка демократии. URL: http://old.russ.ru/politics/meta/20010220_toc.html

3. Гегель Г.В.Ф. Философия права. М., 1990.

4. Нерсесяни В.С. Философия права: учебник для вузов. М., 2013.

5. Выступление В.В. Путина на Общероссийском форуме «Государство и гражданское общество: сотрудничество во имя развития» 15 января 2015 г. URL:http://www.kremlin.ru/events/ president $/$ news $/ 47480$

6. Взаимодействие гражданского общества и государства в России: правовое измерение / кол. авт.; под ред. О.И. Цыбулевской. Саратов, 2013.

7. Выступление Владимира Путина перед доверенными лицами 12 февраля 2004 г. URL: https://ria.ru/economy/20040212/526080.html

8. Хлопин А.Д. Гражданское общество в России: идеология, утопия, реальность // Pro et Contra. 2002. № 1 .

9. Зорькин В.Д. Стандарт справедливости. URL: https://rg.ru/2007/06/08/zorkin.html

10. Абражеева Д.В., Музыкин А.А. Гражданское общество современной России // Актуальные проблемы права: материалы VI междунар. науч. конф. (Москва, декабрь 2017 г.). М., 2017. 